\title{
Islamic Banking: A New Approach for Financial Inclusion
}

\author{
Khaled Zohdi Zamer ${ }^{1}$ \\ ${ }^{1}$ Mobile Money Specialist - Researcher, Jordan \\ Correspondence: Khaled Zohdi Zamer, Al Fattan currency house, $23^{\text {rd }}$ Floor, DIFC, Dubai. Tel: 971-555-472-246. \\ E-mail: Khaled.zamer@gmail.com
}

Received: April 21, 2018

Accepted: May 7, 2018

Online Published: May 30, 2018

doi:10.5539/ijef.v10n7p118

URL: https://doi.org/10.5539/ijef.v10n7p118

\begin{abstract}
This study aimed to explore using Islamic banking as a new approach to tackle the challenges of financial inclusion in Middle east and sub-Saharan Africa where the majority of populations are Muslims and have challenges in accessing the financial instruments. There are different barriers to financial inclusion, one of these is the voluntary exclusion due to religious reasons and the other is the high cost of interest charged to small borrowers. Islamic banking seems to offer reasonable solution to these challenges where the interest is replaced with other tools based on partnerships and social cooperation. However, banks might be facing different type of challenges such as the regulation and customer reach in absence of profitable margins. The other factors impacting adoption will be to offer an economic access to the service without heavy investments from the banks, and maintain high service standard to create trust and drive adoption.
\end{abstract}

Keywords: Islamic banking, mobile money, Islamic financial inclusion mobile money service pillars

\section{Introduction}

Of the 2 billion unbanked people, Middle East is the home of 85 million unbanked adults, and despite the region's financial inclusion woes, there is room for optimism. There is no doubt that access to financial services is becoming more important than ever to help in building sustainable and quality livelihood for the people and ensure the stability of socio-economical system. The majority of population in middle east and sub-Saharan Africa are Muslims yet this is the least financially inclusive part of the world. This paper study the relation between Islamic banking, economic development and customer perception to improve financial access to the mass population by reducing the voluntary exclusion barriers.

\subsection{Islamic Banking Financial Instruments}

Sharia'a- compliant Islamic banking is based on one key principle "Money be used for the purpose of making money" where all transactions must be exchanged for assets, Kettel (2011) stated that actual exchange of real assets is a necessary condition for the contract to comply with Sharia'a principle.

Here is a list of famous Islamic banking products:

Murabaha (cost-plus) may also refer to a sales contract, the Islamic bank sells a specific asset to a customer at a pre-agreed profit mark-up on the original cost, and paid by customer in instalments until the customer monthly payments covers the bank's selling price.

Bai Salam is a forward sale, which require the buyer to pay in advance for specified assets, which the seller agrees to supply on a future date. This is often used in manufacturing, agriculture and processed products.

Ijara (leasing) is an agreement the bank and customer to purchase an asset and then lease it back to the customer for a period against fixed rental instalments. The bank must retain the risk and liabilities of asset ownership including maintenance.

Istisna'a is another form of forward sales, where agreement to sell a non-existent asset to a customer, which is to be produced for future delivery at an agreed prices and quality specifications. The meaning of Istisna'a in Arabic is asking someone to manufacture, which frame the agreement between the seller and the customer.

Takaful is a Sharia'a compliant system of "solidarity "or "mutual guarantee" a form of insurance where the participants in the Takaful agreement donate part of their contribution to pay claims for damages suffered by some of the participants. 
Mudarabah is a contract between the investor who contribute money and the entrepreneur who will work with it to create profitable business. The investor bears all loses and the entrepreneur earns a profit share. The two-tier Mudarabah constitutes of two transactions, one between the depositing customers and one between the bank and client who is asking for funding. In the first transaction, the depositor bears the risk of losses and profits on pre-agreed ratio and the second transaction, the bank bears all losses except in cases of fraud.

Musharka Is a contract between the investor and entrepreneur in which the two partners share profit and loss. Since the Sharia doesn't allow interest in lending, this concept allows the financier to earn profits from the earnings of the business.

\subsection{The Study Motivation}

This paper is an attempt to explore using Islamic banking products to overcome the barriers in financial inclusion in Middle east and sub-Saharan Africa as alternative to conventional banking.

\subsubsection{Financial Inclusion}

The term financial inclusion refers to providing both individuals and businesses responsible and sustainable access to financial products. Although there are some critics to the financial inclusion, yet it is being directly linked to reducing poverty and improving the wellbeing. There are different initiatives taken towards building a cost effective banking for the mass through technology to reduce the cost of banking operational expenses. Financial inclusion is all about offering a safe, secure and affordable financial services. The easiest and most accessible method for financial inclusion is mobile technologies, where in December 2015, over a billion transaction were conducted using mobile money (GSMA, 2016). Out of 93 markets where mobile money is available, 37 has more registered customers than banks while worldwide registered customers crossed 411 million, $52 \%$ of these are in sub-Saharan Africa

\subsubsection{The Barriers to Financial Inclusion}

Fungacova and Weill (2014) grouped the barriers in 5 categories:

- Lack of documentation,

- Lack of trust in financial institutions

- Religion

- A family member having an account

- Having no need for financial services

(Peter, 2017) studied the Impact of each group from Findex data, as illustrated in the below table.

\begin{tabular}{|c|c|c|c|c|c|c|c|c|c|}
\hline VARIABLES & $\begin{array}{r}\text { Too far } \\
\text { away }\end{array}$ & $\begin{array}{l}\text { Too } \\
\text { expensive }\end{array}$ & $\begin{array}{c}\text { Lack of } \\
\text { documentation }\end{array}$ & Lack trust & $\begin{array}{c}\text { Religious } \\
\text { reasons }\end{array}$ & $\begin{array}{l}\text { Lack } \\
\text { money }\end{array}$ & $\begin{array}{c}\text { Family } \\
\text { member } \\
\text { already has }\end{array}$ & $\begin{array}{l}\text { Cannot get } \\
\text { one }\end{array}$ & $\begin{array}{c}\text { No need for } \\
\text { financial } \\
\text { service }\end{array}$ \\
\hline Fourth $20 \%$ & $\begin{array}{l}-0.214^{* *} \\
(0.106)\end{array}$ & $\begin{array}{c}-0.274 * * * \\
(0.103)\end{array}$ & $\begin{array}{l}-0.195^{*} \\
(0.107)\end{array}$ & $\begin{array}{r}-0.123 \\
(0.106)\end{array}$ & $\begin{array}{l}-0.222^{* *} \\
(0.107)\end{array}$ & $\begin{array}{l}-0.181^{*} \\
(0.107)\end{array}$ & $\begin{array}{r}-0.166 \\
(0.107)\end{array}$ & $\begin{array}{l}-0.216^{* *} \\
(0.106)\end{array}$ & $\begin{array}{l}-0.200^{*} \\
(0.107)\end{array}$ \\
\hline Middle $20 \%$ & $\begin{array}{c}-0.335^{* * * *} \\
(0.104)\end{array}$ & $\begin{array}{l}-0.354 * * * \\
(0.102)\end{array}$ & $\begin{array}{l}-0.428 * * * \\
(0.104)\end{array}$ & $\begin{array}{l}-0.343 * * * \\
(0.103)\end{array}$ & $\begin{array}{l}-0.386 * * * \\
(0.105)\end{array}$ & $\begin{array}{l}-0.375 * * * \\
(0.105)\end{array}$ & $\begin{array}{c}-0.411^{* * * *} \\
(0.104)\end{array}$ & $\begin{array}{l}-0.372^{* * *} \\
(0.104)\end{array}$ & $\begin{array}{l}-0.386^{* * *} \\
(0.104)\end{array}$ \\
\hline Second $20 \%$ & $\begin{array}{c}-0.439 * * * \\
(0.103)\end{array}$ & $\begin{array}{l}-0.409 * * * \\
(0.101)\end{array}$ & $\begin{array}{l}-0.469 * * * \\
(0.103)\end{array}$ & $\begin{array}{l}-0.371^{* * * *} \\
(0.102)\end{array}$ & $\begin{array}{l}-0.470 * * * \\
(0.103)\end{array}$ & $\begin{array}{l}-0.453^{* * * *} \\
(0.103)\end{array}$ & $\begin{array}{l}-0.495^{* * * *} \\
(0.103)\end{array}$ & $\begin{array}{c}-0.460 * * * \\
(0.103)\end{array}$ & $\begin{array}{l}-0.454^{* * * *} \\
(0.103)\end{array}$ \\
\hline Poorest $20 \%$ & $\begin{array}{c}-0.569 * * * \\
(0.0994)\end{array}$ & $\begin{array}{l}-0.481^{* * *} \\
(0.0975)\end{array}$ & $\begin{array}{l}-0.565 * * * \\
(0.0997)\end{array}$ & $\begin{array}{l}-0.502^{* * *} \\
(0.0986)\end{array}$ & $\begin{array}{l}-0.567 * * * \\
(0.0996)\end{array}$ & $\begin{array}{l}-0.555^{* * * *} \\
(0.0996)\end{array}$ & $\begin{array}{c}-0.586^{* * * *} \\
(0.0997)\end{array}$ & $\begin{array}{l}-0.569 * * * \\
(0.0995)\end{array}$ & $\begin{array}{l}-0.577^{* * *} \\
(0.0996)\end{array}$ \\
\hline Secondary & $\begin{array}{c}-0.655^{* * * *} \\
(0.0736)\end{array}$ & $\begin{array}{l}-0.654^{* * * *} \\
(0.0721)\end{array}$ & $\begin{array}{l}-0.699 * * * \\
(0.0740)\end{array}$ & $\begin{array}{c}-0.676^{* * *} \\
(0.0736)\end{array}$ & $\begin{array}{l}-0.670^{* * *} \\
(0.0738)\end{array}$ & $\begin{array}{l}-0.705 * * * \\
(0.0740)\end{array}$ & $\begin{array}{l}-0.674^{* * * *} \\
(0.0740)\end{array}$ & $\begin{array}{c}-0.697 * * * \\
(0.0738)\end{array}$ & $\begin{array}{l}-0.687^{* * * *} \\
(0.0738)\end{array}$ \\
\hline Completed primary or less & $\begin{array}{l}-1.231^{* * *} \\
(0.146)\end{array}$ & $\begin{array}{l}-1.125 * * * \\
(0.141)\end{array}$ & $\begin{array}{c}-1.197 * * * \\
(0.143)\end{array}$ & $\begin{array}{c}-1.176^{* * *} \\
(0.143)\end{array}$ & $\begin{array}{c}-1.187 * * * \\
(0.143)\end{array}$ & $\begin{array}{c}-1.209 * * * \\
(0.143)\end{array}$ & $\begin{array}{c}-1.182^{* * *} \\
(0.143)\end{array}$ & $\begin{array}{c}-1.217^{* * * *} \\
(0.144)\end{array}$ & $\begin{array}{l}-1.228^{* * *} \\
(0.144)\end{array}$ \\
\hline Age & $\begin{array}{c}-0.0407^{* * *} * \\
(0.00904)\end{array}$ & $\begin{array}{r}-0.0396^{* * *} \\
(0.00886)\end{array}$ & $\begin{array}{c}-0.0438^{* * *} \\
(0.00909)\end{array}$ & $\begin{array}{c}-0.0414^{* * *} \\
(0.00901)\end{array}$ & $\begin{array}{c}-0.0406^{* * *} \\
(0.00907)\end{array}$ & $\begin{array}{c}-0.0412^{* * *} * \\
(0.00907)\end{array}$ & $\begin{array}{c}-0.0447^{* * *} * \\
(0.00909)\end{array}$ & $\begin{array}{c}-0.0430^{* * *} \\
(0.00906)\end{array}$ & $\begin{array}{c}-0.0410^{* * *} \\
(0.00906)\end{array}$ \\
\hline Female & $\begin{array}{c}-0.0901 \\
(0.0628)\end{array}$ & $\begin{array}{l}-0.0800 \\
(0.0616)\end{array}$ & $\begin{array}{c}-0.111^{*} \\
(0.0630)\end{array}$ & $\begin{array}{l}-0.0823 \\
(0.0626)\end{array}$ & $\begin{array}{l}-0.112^{*} \\
(0.0630)\end{array}$ & $\begin{array}{l}-0.0879 \\
(0.0630)\end{array}$ & $\begin{array}{l}-0.0969 \\
(0.0630)\end{array}$ & $\begin{array}{l}-0.0728 \\
(0.0628)\end{array}$ & $\begin{array}{l}-0.106^{*} \\
(0.0630)\end{array}$ \\
\hline Has debit card & $\begin{array}{l}-0.392 \\
(0.344)\end{array}$ & $\begin{array}{c}-0.400 \\
(0.316)\end{array}$ & $\begin{array}{c}0.147 \\
(0.292)\end{array}$ & $\begin{array}{c}0.161 \\
(0.286)\end{array}$ & $\begin{array}{l}-0.369 \\
(0.333)\end{array}$ & $\begin{array}{r}-0.150 \\
(0.312)\end{array}$ & $\begin{array}{l}0.0166 \\
(0.297)\end{array}$ & $\begin{array}{c}0.314 \\
(0.289)\end{array}$ & $\begin{array}{l}-0.361 \\
(0.341)\end{array}$ \\
\hline Domestic remittances & $\begin{array}{l}0.00607 \\
(0.0642)\end{array}$ & $\begin{array}{l}-0.0279 \\
(0.0629)\end{array}$ & $\begin{array}{c}0.0112 \\
(0.0642)\end{array}$ & $\begin{array}{l}-0.0122 \\
(0.0639)\end{array}$ & $\begin{array}{c}0.0291 \\
(0.0644)\end{array}$ & $\begin{array}{c}-0.000337 \\
(0.0643)\end{array}$ & $\begin{array}{l}-0.00423 \\
(0.0643)\end{array}$ & $\begin{array}{l}-0.00395 \\
(0.0641)\end{array}$ & $\begin{array}{c}0.0126 \\
(0.0643)\end{array}$ \\
\hline Government transfers & $\begin{array}{l}1.319 * * * * \\
(0.0644)\end{array}$ & $\begin{array}{l}1.235^{* * * *} \\
(0.0634)\end{array}$ & $\begin{array}{l}1.324 * * * \\
(0.0644)\end{array}$ & $\begin{array}{l}1.324 * * * \\
(0.0641)\end{array}$ & $\begin{array}{l}1.332^{* * * *} \\
(0.0644)\end{array}$ & $\begin{array}{l}1.334 * * * \\
(0.0643)\end{array}$ & $\begin{array}{l}1.333^{* * * *} \\
(0.0645)\end{array}$ & $\begin{array}{l}1.317^{* * * *} \\
(0.0643)\end{array}$ & $\begin{array}{l}1.322 * * * \\
(0.0643)\end{array}$ \\
\hline Saved & $\begin{array}{c}0.698 * * * \\
(0.0718)\end{array}$ & $\begin{array}{l}0.637 * * * \\
(0.0699)\end{array}$ & $\begin{array}{l}0.692^{* * * *} \\
(0.0720)\end{array}$ & $\begin{array}{l}0.661 * * * \\
(0.0714)\end{array}$ & $\begin{array}{l}0.715^{* * * *} \\
(0.0721)\end{array}$ & $\begin{array}{l}0.665^{* * * *} \\
(0.0719)\end{array}$ & $\begin{array}{l}0.680 * * * * \\
(0.0720)\end{array}$ & $\begin{array}{l}0.650 * * * \\
(0.0716)\end{array}$ & $\begin{array}{l}0.667 * * * \\
(0.0718)\end{array}$ \\
\hline Borrowed & $\begin{array}{l}-0.124^{*} \\
(0.0689)\end{array}$ & $\begin{array}{l}-0.131^{*} \\
(0.0675)\end{array}$ & $\begin{array}{c}-0.105 \\
(0.0690)\end{array}$ & $\begin{array}{l}-0.126^{*} \\
(0.0686)\end{array}$ & $\begin{array}{l}-0.114^{*} \\
(0.0691)\end{array}$ & $\begin{array}{l}-0.127^{*} \\
(0.0691)\end{array}$ & $\begin{array}{l}-0.124^{*} \\
(0.0691)\end{array}$ & $\begin{array}{l}-0.0740 \\
(0.0688)\end{array}$ & $\begin{array}{c}-0.0809 \\
(0.0690)\end{array}$ \\
\hline Constant & $\begin{array}{c}-0.518 \\
(0.443)\end{array}$ & $\begin{array}{c}-0.408 \\
(0.420)\end{array}$ & $\begin{array}{c}-0.951 * * \\
(0.405)\end{array}$ & $\begin{array}{c}-1.041 * * * \\
(0.402)\end{array}$ & $\begin{array}{l}-0.576 \\
(0.432)\end{array}$ & $\begin{array}{l}-0.678 \\
(0.419)\end{array}$ & $\begin{array}{c}-0.786^{*} \\
(0.410)\end{array}$ & $\begin{array}{c}-1.130 * * * \\
(0.403)\end{array}$ & $\begin{array}{r}-0.517 \\
(0.438)\end{array}$ \\
\hline Observations & 2,384 & 2,384 & 2,384 & 2,384 & 2,384 & 2,384 & 2,384 & 2,384 & 2,384 \\
\hline
\end{tabular}


The study concluded that lack of money, distance to service points and the cost of transaction are being the most critical barriers to financial inclusion. However, other studies highlighted religion has another dimension in contributing to financial exclusion. (Knight 2006) affirmed that "The spread of Islamic financial services would help combat social and financial exclusion between UK's 1.6 million Muslims".

\subsection{Source Data}

- $\quad$ IFC publications;

- $\quad$ Global Findex data (World bank);

- Demographic data (World bank, IMF, Country profiles);

- $\quad$ Number of account holders (Central banks, annual reports);

- $\quad$ Cross country comparison of financial inclusion (CGAP, Financial inclusion measurement, 2017).

\section{Assets Growth and Challenges}

According to the World Islamic Banking Competitiveness report published by:

Ernst and Young (2012) in Banking Competitiveness report stated that "Islamic banking assets grew to $\$ 1.3$ trillion in 2011, with an average growth of $19 \%$ annually over past four years".

The Islamic banking industry continues to grow exponentially, faster than their commercial banking peers and seems to be appealing to the industry with many of international banking giants tapping into this market. Khamis and Senhadji (2010), Hassan and Dridi (2010), Rashwan (2012), and Merchant (2012) studied the contrast between Islamic banks and Conventional banks on both pre and post the financial crisis, these studies highlighted that performance and efficiency of Islamic banks during the crisis was better than the conventional banks counterparts; the mechanism Islamic Sharia'a proved better resilience to negative profitability and speculation which impacted conventional banks. This led to the exceptional adoption of Islamic Banking principles to stabilize the financial systems and regain investors' confidence in the banking industry as affirmed by Jusufovic (2009).

Ernest and Yong predict a 14\% growth in Islamic banking by 2020 to exceed 1.8 trillion USD with Saudi Arabia leading the industry with 683 billion, the total liabilities for Islamic banks were $21.8 \%$ in 2014 \& expected to reach the level (22\%-25\%) of total liabilities of the banking system in 2015 (ABJ, Annual Report, 2014). Total Assets of Islamic Banks (LAIB) can predict the economic growth as affirmed by AL-Hersh (2016) as well (Ahmad, 2004) and (Muhamad \& Azmi, 2012) predicted that Islamic banking would control over 50\% of savings in the Islamic countries within the next decade. With the previous researches confirming Islamic banking can drive the economic growth similar to conventional banking there is an emerging need to develop more cohesive financial products designed to the low income poor, however the outreach of formal financial services in the Arab world stands at only 21 percent when excluding the Gulf Cooperation Council (GCC) countries, the lowest worldwide as highlighted in the CGAP report (2017).

According to the Findex Note on Financial Inclusion in the Middle East (Demirguc-Kunt et al., 2015), account ownership is the lowest, most notably for women, low income people, and youth which represent the majority of Middle East population. CGAP report highlighted the region shows equal or higher financial activity, but lower outreach of formal financial services, be it for account ownership or for credit. This gap between demand, accessibility can be bridged by offering a wider access channel to financial instruments at a lower cost of service which can maintain the profitability ratios for the Islamic banking sector. To build a partnership model between Islamic banks and the low income Asli (2013) highlighted key questions relevant to the Islamic finance industry:

(1) Are Muslims less likely than non-Muslims to use formal financial services in their current form?

(Demirguc-Kunt et al., 2015) affirmed that having Islamic banking products could potentially increase the number of adults with accounts by $10 \%$ in MENA and 5\% in Asia. However, when eliminating the religious factors, both Muslims and non-Muslims share the same concerns impacting owning a formal account. When examining the religious factors independently, Muslims are more likely to report religion as the main barrier for owning an account.

With this in mind, there is a definitive need to offer Islamic products to the mass in order to avoid further exclusions of the poor, Sana and Naushadul (2016) concluded to increase financial inclusion, countries with higher Islamic population need to develop products that are compatible with the principles of Islamic finance.

(2) Do unbanked Muslims differ from unbanked non-Muslims in their barriers to financial inclusion?

Both non-Muslims and Muslims are sensitive to pricing, distance to point of service, and documentation as 
barriers to account ownership. However, having Islamic banking products offered at reasonable cost and within reach should theoretically increase adoption and neutralize the religious factors associated with voluntary exclusion. A study by (CGAP, 2016) confirmed that the demand for Sharia compliant loans were reported higher when both the Islamic loan and conventional loans were marketed independently and at the same cost where $20 \%$ more customers opted for a loan when offered an Islamic product verses the conventional loans. With this in mind, there is a higher probability to attract more people into the financial system when offering Islamic products to public than if conventional was the only option.

(3) Does the customer distinguish between the different Islamic financial products?

Izah Tahir (IBTRA) highlighted 5 gaps between customer expectations versus awareness and quality of services offered by Islamic banks:

- Understanding: the difference between customer expectations and management perceptions;

- Service standards: the difference between management perceptions and service quality specifications;

- Service performance: the difference between service quality specifications and the service actually delivered;

- Communications: the difference between service delivery and customer communication;

- Service quality: the difference between service quality and customer perceptions of the organization's performance.

And concluded that customers using Islamic banking products are not fully aware of the different products and services as well there is lack of regulatory framework with absence of international Sharia board widen the gap and would cause misconceptions.

(4) Are Muslims willing to pay a premium for Sharia-compliant financial products and services?

Oliver (2011) indicated that banking clients are willing to pay a premium for Islamic banking services, and a majority of Muslim customers who currently use conventional banking products claim that they would switch if Islamic products were available. However, there is a need to build the right balance when setting the pricing structure to serve two objectives, follow the Islamic finance guide lines and ensure customers are not excessively charged for the service, and maintain profitable margins to the banks. The banks can offer modern products using Shaira principles in a way that can promote financial stability and growth to millions of Muslims who abstain from using banking products for religious reasons, a good example for that can be seen in Ijarah and Murabaha primarily in mortgage and financing.

(5) What are the barriers for owning a bank account?

Gallup research on number of bank account holders (2015) showed a growth in number of adults whose been introduced to financial services, however with $43 \%$ of the world unbanked population resides in middle east and sub-Saharan Africa there is a big room for improvement. The Muslim population represent $30 \%$ of the sub-Saharan Africa and 91\% of the Middle east region according to Pew research centre (2011).

From the world bank study, we notice that offering Islamic financial products can slightly improve the customer perception to help in bringing more people into the financial system, yet this contribution cannot be quantified for the lack of regulations and number of institutions offering Shaira compliant microloans. On the other hand, IFC and CGAP studies showed high potential when Islam financial products versus the conventional banking.

\section{Findings and Recommendations}

The success of Islamic financial inclusion is based on three pillars (Product structure, Access Channels, Service Quality):

- $\quad$ Product structure and pricing:

Banks in general and Islamic banks in specific needs to offer financial products that can cater for the mass market and specifically design services with the following principles in mind (Low cost, Mobile, minimum collaterals, accessible and easy to use), Becky Carter (2013) highlighted different reasons for exclusions which must be considered when designing new products to ensure proper adoption and benefits.

- Institutional formal exclusion: Where banks and microcredit opt to avoid doing business with the poor or people in remote areas;

- Institutional formal exclusion: sales agents avoiding offering services to people with certain segments;

- Client informal exclusion: lack of confidence, trust or awareness; 
- Client exit: if the institution is not implementing pro-poor policies the clients will not do repetitive transactions.

Rajiv and Ishan (2015) indicated that target marketing is the key driver for adoption as that provides customer with the right education on usage, as well when certain behaviours are incentivized customer are more likely to use the service

\section{- $\quad$ Access channels}

Despite the increase in number of branch networks ATM access and availability of online banking services the gap between rich and developing countries is still big. There are 47 ATMs and 17 commercial bank branches per 100,000 adults globally in 2011. While lower-middle-income regions use 3.2 branches and 13.1 ATMs per 100,000 respectively, this figure is 76 in upper middle-income countries and 123 in high-income. This is showing a higher need for a more viable and economic ways to reach people especially in remote areas. Banks deploy ATM devices in main cities, shopping centres and other urban areas where there is a need and potential of use as well access to customer who in nature are mostly have a bank account, while the actual need remains in rural under developed regions. The GSMA real-time tracker showing more than 8 billion devices and over 5 billion unique mobile subscribers. This might give the answer to which channel can reach most of the customers in the shortest period without compromising the profitability margins for the bank. While mobile financial services seem to be the answer to all financial inclusion access, there are still some roadblocks in the way such as regulation, KYC and building the ecosystem as well the technology might not help all the time where mobile network coverage is not available, advanced $3 \mathrm{G}$ services are not affordable and absence of a national ID platform. However, despite all these burdens mobile remain the best option for now. The policy makers need to work on regulations to allow banks, correspondent banking and digital only banks to operate freely to offer financial services to the mass public.

\section{- $\quad$ Service quality}

It is without doubt, that service availability and quality plays a significant role in building trust and deliver value which in turn translates into recurring transactions and results in profitable operation. Houn-Gee (2012) affirmed that service quality not only has a positive impact on customer satisfaction, but also plays a role gaining customers' trust and deliver value, which in turn lead to customer satisfaction. Zeithaml (1987) mentioned that service quality is considered to be a cornerstone in the customer perception towards trust and excellence. With the later in mind (Crosby, 1991; Reichfeld \& Sasser, 1990; Edvardsson \& Gustavsson, 1991; Adil, 2012; Adil, 2013a, Adil, 2013b) summarized the direct impact of service quality on customer perception:

- $\quad$ Satisfied and retained customers and employees

- Opportunities for cross-selling;

- The attraction of new customers;

- Development of customer relationships;

- Enhanced corporate image;

- $\quad$ Reduced costs and increased profit margins and business performance.

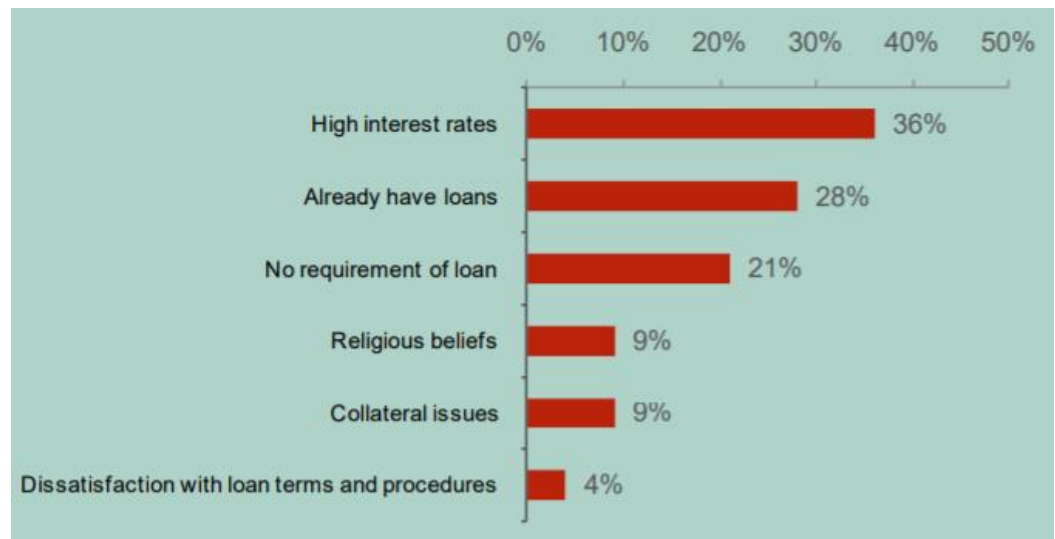

The banks should focus on delivering a service quality to the end customer at an affordable price to ensure they maximise the benefits from financial products which in return will reflect on banks profitability and economic development. 


\section{Conclusion}

Islamic Banking is getting momentum globally with conventional banks offering Islamic complaint products and growth of Islamic banking assets to exceed \$3.4 trillion and expected to grow 19.7\% through 2018. However, there is still a gap between demand for financial products that are secure, safe, sustainable and reasonable fees and what's been offered by Islamic banks to people with medium to low income. Customers need to have transparent product and pricing structure, availability of access channels, and service quality which comes at a price for banks that are not able to offer that to mass public. When Islamic banks partner with mobile operators to deliver the service it may solves two challenges (Reduce the cost of operation for the bank, offer social responsible banking services) and that will help customers to overcome the voluntary exclusion for religious reasons and promote economic development. Any products offered must consist of transparent product and pricing structure, easy to use, offered through different digital channels and the service quality should match that offered to affluent segments. Banks can charge a premium to reduce the risk factors and increase the profit margins. On the global industry level, there are still variances

\section{References}

AL-Hersh, N. F. (2016). The Impact of Jordan's Conventional and Islamic Banking Development Factors on Economic Growth. International Journal of Economics \& Finance, 8(9), 148. https://doi.org/10.5539/ijef.v8n9p148

Anonymous. (n. d.). Quality classics Crosby's fourteen steps to improvement. Quality Progress, 61-64. Retrieved from http://www.calidadpr.com/enlaces_descargas/qp1205crosby.pdf

ATKearney. The future of Islamic Banking. Retrieved from https://bit.ly/2HZiCv0

Carte, B. (2013). Helpdesk Research Report: Evidence on microcredit for the ultra-poor. Governance \& Social Development Resource Centre University of Birmingham.

CGAP. (2012a). Oya Ardic Pinar, Imboden, Kathryn and Latortue Alexia - Financial Access.

CGAP. (2012b). Getting to a More Comprehensive Picture. Retrieved from https://www.cgap.org/sites/default/files/cgap_forum_FAS2012.pdf

CGAP. (2017). Financial Inclusion Measurement in the Arab World. Retrieved from http://www.cgap.org/sites/default/files/Working-Paper-Financial-Inclusion-Measurement-in-the-Arab-World _1.pdf

Crosby, P. B. (1979). Quality is free. New York: McGraw-Hill.

Deloitte. (). The Digital Islamic Services landscape. Retrieved from http://www.iedcdubai.ae/assets/uploads/files/ar_me_Islamic-Digital-Services_1464241308.pdf

Demirguc-Kunt, A., Leora, K., \& Douglas, R. (2013). Islamic Finance and Financial Inclusion. The World Bank $\begin{array}{llllll}\text { Policy research } & \text { working } & \text { paper } & \text { Retrieved }\end{array}$ http://documents.worldbank.org/curated/en/611351468337493348/pdf/WPS6642.pdf

Dittus, P., \& Klein, M. (2011). On harnessing the potential of financial inclusion. BIS Working Papers No 347. https://www.bis.org/publ/work347.pdf

EY. (2016). World Islamic Banking Competitiveness Report 2016. Retrieved from https://go.ey.com/2rr1tmy

Farahani, Y. G., \& Sadr, S. M. H. (2012) Analysis of Islamic Bank's Financing and Economic Growth: Case Study Iran and Indonesia. Journal of Economic Cooperation \& Development, 33. https://www.questia.com/library/journal/1P3-3052233181/analysis-of-islamic-bank-s-financing-and-econo mic

GSMA. (2016). Mobile money. State of Industry Report 2016. Retrieved from https://bit.ly/2JUbbG0

IFSL Research. (2008). Islamic Finance 2008.

Johnson, K. (2013). The Role of Islamic Banking in Economic Growth. Retrieved from https://bit.ly/2wkdZKw

Kettle, B. (2011). Introduction to Islamic Banking and Finance. Wiley. https://doi.org/10.1002/9781118467299

Knight, J. (2006). Islamic Banking goes nationwide. BBC News. Retrieved from http://news.bbc.co.uk/2/hi/business/5075998.stm

Mavrakis, N. (2009). Islamic Finance- A vehicle for economic development. Islamic Finance.

Mohamed, S. M. R. (2016). Financial Exclusion in Australia: Can Islamic Finance Minimise the Problem? 
Australasian Accounting, Business and Finance Journal, 10(3), 89-104.

Mohd, A., Al-Ghaswyneh, O. F. M., \& Alaa, M. A. (2013). SERVQUAL and SERVPERF: A Review of Measures in Services Marketing Research. International Journal of Advanced Nursing Studies, xiii(2), 65-76.

Muriu, P. (2017). Barriers of Financial Inclusion in Sub-Saharan Africa. Journal of Economics and Sustainable Development, 8(14).

Oliver, W. (2014). Islamic Finance, Building 150 financial institutions by 2020. Retrieved from https://owy.mn/2rnggPY

Peter, V. O., \& Jan, S. (2015). Number of Bank Account Owners Worldwide Grows by 700 Million. Retrieved from http://news.gallup.com/poll/182420/number-bank-account-owners-worldwide-grows-700-million.aspx

Rajiv, L., \& Ishan, S. (2015). Mobile Money Services - Design and Development for Financial Inclusion. Retrieved from https://hbs.me/2EFFGfC

Tahir, I. M., \& Haron, S. (2010). Cost and profit efficiency of Islamic banks: international evidence using the stochastic frontier approach. Banks and Bank Systems, 5(4).

Zera, A., Arganb, M. T.,\& Arganc, M. (2013). The effect of mobile service quality dimensions on customer satisfaction. Procedia - Social and Behavioral Sciences, 99, 428-438. https://doi.org/10.1016/j.sbspro.2013.10.511

Zuzana, F., \& Laurent, W. (2015). Understanding financial inclusion in China. China Economic Review, 34, 196-206. https://doi.org/10.1016/j.chieco.2014.12.004

\section{Copyrights}

Copyright for this article is retained by the author(s), with first publication rights granted to the journal.

This is an open-access article distributed under the terms and conditions of the Creative Commons Attribution license (http://creativecommons.org/licenses/by/4.0/). 